\title{
Did the Latin poet Lucan report an Ebola virus disease outbreak in his epic Pharsalia? An epidemiological report in Roman literature
}

Giovanni Meledandri ${ }^{1, *}$ and Leonardo Borgese ${ }^{2}$

${ }^{1}$ Università degli Studi Guglielmo Marconi - Department of Human Sciences. Rome, Italy

${ }^{2}$ Leonardo Borgese - La Sapienza Università di Roma - Department of Infectious Diseases. Rome, Italy

*Corresponding author: Giovanni Meledandri, Università degli Studi Guglielmo Marconi - Department of Human Sciences. Rome, Italy Received date: 22 November, 2021 Accepted date: 2 December, 2021

Published date: 5 December, 2021

Citation: Meledandri G, Borgese L. (2021) Did the Latin poet Lucan report an Ebola virus disease outbreak in his epic Pharsalia? An epidemiological report in Roman literature. J Virol Viral Dis 1(2). doi https://doi.org/10.54289/JVVD2100106

Copyright: C 2021 Meledandri G, Borgese L. This is an open-access article distributed under the terms of the Creative Commons Attribution License, which permits unrestricted use, distribution, and reproduction in any medium, provided the original author and source are credited.

Keywords: Ebola virus; EVD; epidemiology; outbreak; history; Latin language; Lucan; Roman; Pharsalia

Abbreviations: EVD: Ebola virus disease.

"...our Pharsalia shall live, and we shall be condemned to darkness by no era" (C.V. Lucan, Pharsalia, Liber IX)

\section{Summary}

The authors, analyzing Lucan's epic poem "Bellum civile / Pharsalia", examined the historical premises and the epidemiological conditions useful to understand some facts reported in book IX of the epic, where a probable epidemic infectious disease episode may have been described. After a careful reading of the Latin text and a revision of the phylogenetic history and characteristics of viruses responsible for the African hemorrhagic fevers, the authors suggest that in the text of Lucan may have been reported the very first historical description of an Ebola virus disease (EVD) outbreak.

Over the past six years, the disease from Ebola virus (EVD) has spread repeatedly in areas of tropical Africa, creating outbreaks and larger epidemics and putting other nations in fright and jeopardy. Each outbreak has allowed the disease to manifest itself with different virulence and mortality in absence of therapy. The symptomatology and the clinical course of EVD are those of a typical hemorrhagic viral disease.
In book IX of the Latin epic poem Bellum Civile by Lucan (39 AD - $65 \mathrm{AD}$ ), better known with the title of Pharsalia, an extensive and detailed description of a serious epidemic episode affecting Roman soldiers during their long journey in Africa is inserted. The explanations that Lucan provides are obviously compatible with the knowledge of the time. Considering the numerous affinities between the reported symptoms and the symptomatology of EVD, the authors hypothesize that the report provided by Lucan could have been the very first detailed description of an EVD outbreak. A civil war begins in Rome as Caesar [1] crosses the border of the Rubicon river, entering Italy. As a result, Pompey and the Senate leave Rome, heading to Brundisium. In March of 49 a.E.V (ante Era Vulgare). Pompey sails over to Epirus, while Italy remains under Caesar's control. Caesar and his allies conduct some victorious campaigns, defeating Pompey's generals in Spain. Caesar then comes back to Rome in December of 49 a.E.V. and is elected consul for the following year. In January of 48 a.E.V. Caesar and his army face the Pompeians at Dyrrachium. The opponents wait and make attempts to end up the war in a convenient and bloodless way but do not manage to get rid of personal and political rivalries. The final and decisive battle takes place in Pharsalus on August 9th of 48 a.E.V. 
The army of Pompey was in overwhelming numerical and tactical advantage over that of Caesar, who was strongly favoured. Nevertheless, it underwent a complete defeat, on the reasons of which historical sources do not provide a satisfactory explanation. For the historian and poet Lucan, the inexplicable is exclusively attributable to Fate, which governs the destinies of men and gods. Pompey fled with his family and a group of faithful through the islands of the Aegean, heading to Alexandria. He never reached his destination because he was treacherously killed by order of the fourteen years old Pharaoh Ptolemy XIII, Cleopatra's brother. He was the one to whom Pompey thought - at least at first - to ask for help. According to Lucan the young pharaoh was advised by unscrupulous dignitaries, intent on this gesture to win over the favors of Caesar.

Cato and his followers, chased now by the legions of Caesar, decided to seek shelter to attempt an extreme resistance in the provinces still favorable to Pompey and the Republic. The safest among them was Numidia, governed at the time by King Juba I, hostile to Caesar and protector of the Catonians. The army of fugitives thus undertook the way to the province of Africa (Caesar GJ, Commentarii de Bello Civili, 2.40) [1]. The movements of Caesarians, Pompey and Cato are shown in Fig. 1.

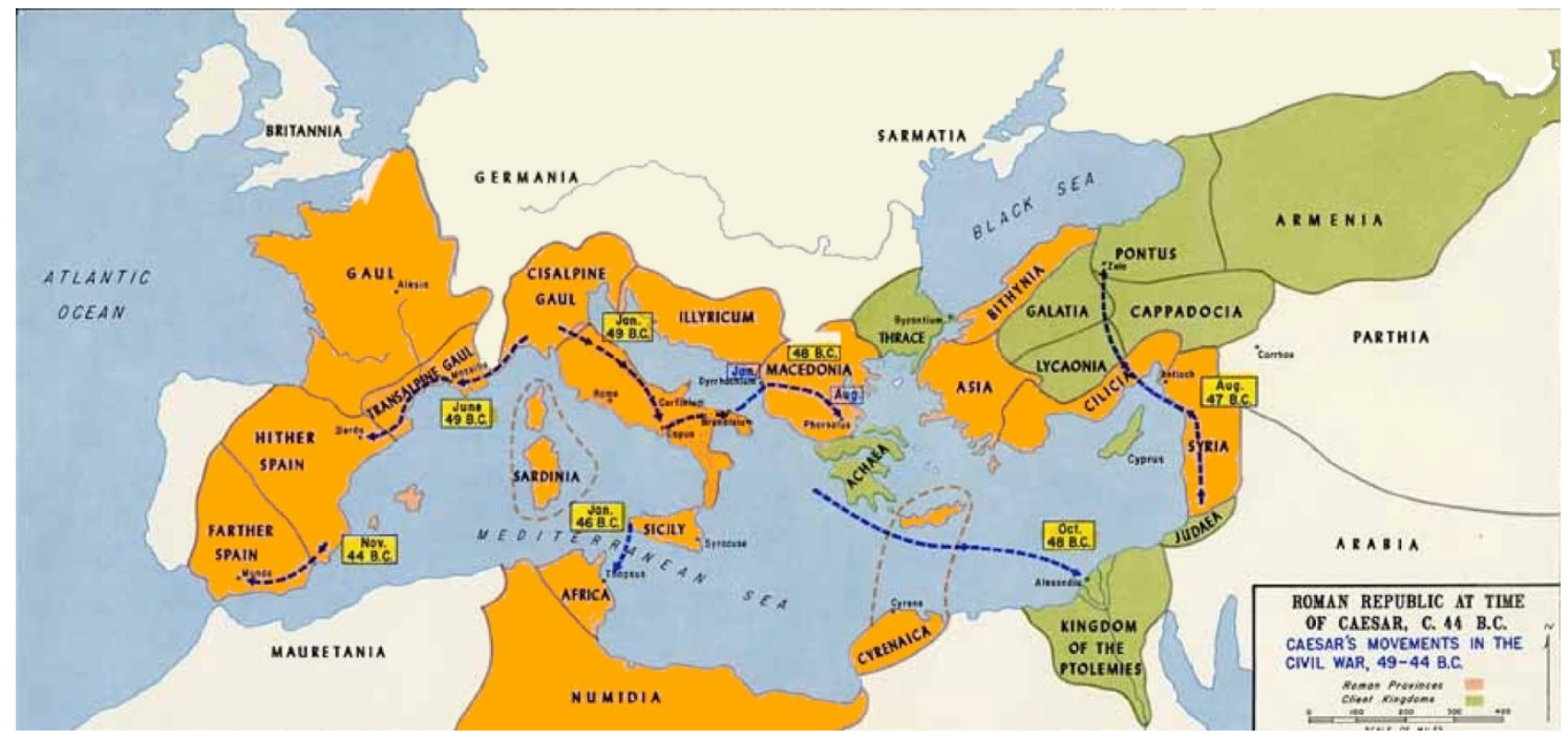

Fig. 1 - Caesar's and Pompey's movements in the Roman Civil War, 49-44 a.E.V. Pompey was defeated at Pharsalus (Aug 9 ${ }^{\text {th }}, 48$ a.E.V.) and this turned the civil war, also paving the way for the end of the Roman republic. Pompey fled to Egypt and there was killed (Sept $28^{\text {th }}, 48$ a.E.V.). The republicans regrouped and headed by Cato and fought on in Africa (47-46 a.E.V.). They suffered the final defeat in Spain (44 a.E.V.).

The Greek geographer Strabo [2] reports that between 48 and 47 of ante E.V. "Marcus Cato, on his march to join Metellus Scipio, travelled round the region of Syrtis Magna by land, in 30 days, leading an army of more than 10,000 men, having separated them into divisions on account of lack of watering facilities, and travelled on foot in deep sand and scorching heat." (Strabo. Geography XVII.3.20) [2].
The travel diary of the expedition is the main topic of Pharsalia's Book IX (Lucan, Bellum Civile IX, 294-937) [3]. Cato's decision to attempt the journey from Cyrene to Juba's kingdom gave Lucan the opportunity to incorporate much material relating to Africa as it was known at his time (Fig.

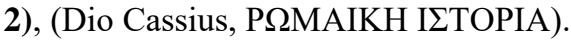




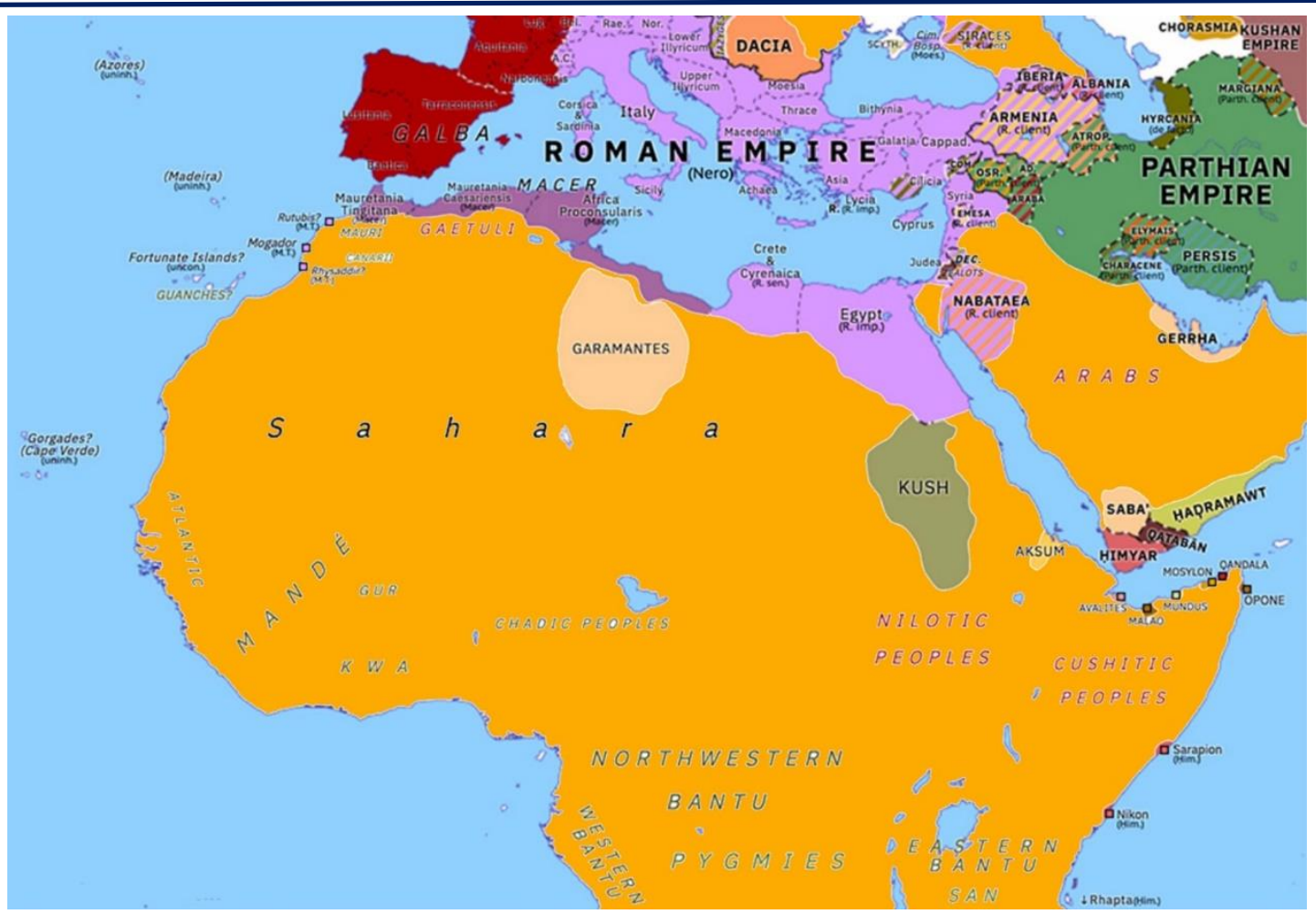

Fig. 2 - Northern Africa 68 E.V. 60-61 E.V. Roman Africa penetration at the time of Nero's Nile expedition, modern map. In around 60 AD the Roman emperor Nero ordered two centurions to lead an expedition to explore the Nile River and attempt to locate its source. Assisted by the King of Kush, the Romans traveled up the White Nile as far as huge, apparently limitless marshes - the Sudd of South Sudan-which they found could only be penetrated by small one-man boats [14]. It's uncertain as to how far they advanced from here, but some of them carried on to an immense waterfall—possibly Murchison Falls in Uganda [10].

The Lucan's description [3] starts with the origin and nature of Syrtes (303-318), a very dangerous area of sandbanks. Cato's fleet had to cross the Syrtes and bring the Romans to land near the lake Tritonis, in present southern Libya.

In the geographical description that follows Lucan identifies the land with Libya, the name generally used to indicate Africa (B.C., IX, 411-462), as shown in the Eratosthenes map, Fig. 5.

Going ahead, Cato and his men arrive at the temple of Juppiter Ammon (B.C., IX, 511-527). Lucan describes the god and his shrine with particular attributes. A description of an oasis that the poet locates on the Equator gives the hand to speculate about astronomical differences experienced by peoples living there (B.C., IX, 528-543): lines 533-537 show a stunning arrangement of the twelve signs of zodiac in opposing pairs (Housman AE, 1950; Lacus Curtius) [5,6].

The temple was not on Cato's route: for what reason did Lucan include this episode?

1) Did Lucan want to use it to give Cato credit and to contrast with Appius' consultation of the Delphic oracle in book V?

2) Does the episode belong to lost material of the book it and was later inserted in book 9 by copyists? Since in this passage Lucan add verses dealing in detail with an exotic astronomical matter (B.C., IX, 528-543), fragmented material, resulting from lost books, could have been pasted in book IX by anonymous hands in the manuscripts edited during the following centuries.

3) Did Lucan simply want to show off his versatility and ability as a history teller, embracing natural history and ethnography? His approach looks very different from authors like Caesar and closer to Greek models as, particularly, Herodotus and Plutarch.

It is hard to rely on any not speculative answer to these questions. It is here that, anyway, Lucan ascribes to the Tropic of Cancer phenomena; many astronomical details regarding this text are treated in the classical Housman's Astronomical Appendix [5]. It seems clear that the trip routed much southward and at a greater distance than it would have been necessary to reach final Cato's destination in Numidia. 
It is also worth saying that, at the time Lucan was writing his poem, information and record were available about tropical Africa. The search for the source of the Nile was highly topical at the time of Lucan. Nero, the emperor, following the precedent of Alexander and some others, all mentioned by Lucan (B.C., X, 268-282) planned explorative expeditions looking for Nile's source and at least one was settled and successfully ruled out from 62 to 67 of E.V. (Dio Cassius, cit.), Fig.2. According to some more authors [7,8] this expedition probably reached the Murchinson Falls, in present Uganda [9,10] (see Fig. 2 and 3).

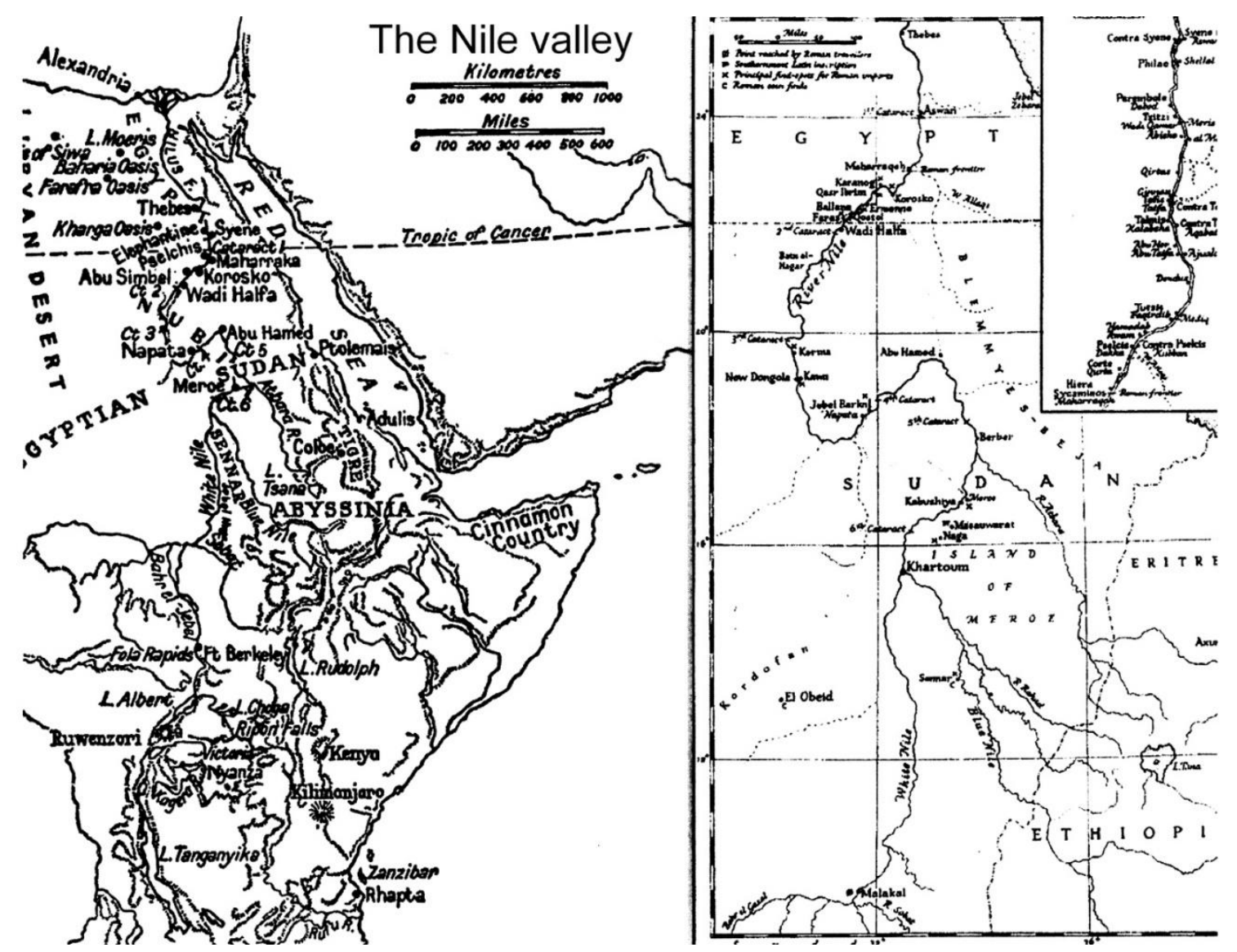

Fig. 3 - The Nile Basin (left) and details (right) maps. Roman Africa Province and possessions as at the age of Lucan Pharsalia (50 E.V.), [13,17] Cartography by Cary M, Warmington EH, The Ancient Explorers, Africa: 202-222, Penguin Books, London, 1963, modif.

Lucan's poem breaks off at Book X, 1.546. Was the book still unfinished at the time of Lucan's premature death (he became disliked by the emperor and committed suicide in 65 E.V.)? Or was the original code mutilated or simply lost? This remains matter for speculation and many, widely different, hypotheses have been advanced.

The most notable scientific digression in Lucan's poem comes from lines 619 to 699 , and it is a catalogue of pests mainly snakes - of Libya which assailed the Romans during their African march. The numerous kinds of snake (B.C., IX, 700-733) and the types of death (B.C., IX, 734-836) they inflicted are catalogued. In the text a local tribe, the Psylli, were immune to the venoms, and able to cure any bite's consequence.

The descriptive analysis of symptoms according to the types of death is in lines 735-815 and is reported in its English translation [11].

735-36: "witnessing so many grim casualties among his soldiers and unfamiliar deaths with tiny wound."

739-41: "Hardly was there a pain or a sensation of a bite, and even death's appearance is not malignant, and the injury does not look threatening ... and devouring fire eats away the marrow and with hot decay it sets the guts ablaze" 
769-74: “...the calves have melted, the knee was bare of covering, and even every muscle of thighs dissolve, and the groin drips with black decay. The membrane which binds the belly burst apart and out melt the entrails; and not as much as there should be from an entire body melt into the ground"

808-14: "Utque solet pariter totis se effundere signis" - "so all his limbs at once emitter ruddy poison, instead of blood. Gore flows abundantly from whatever opening moisture uses; his mouth and spreading nostrils run with it; his sweat turns red; all his limbs are awash with his copious veins; his entire body is one wound ... you die not evidence the bite"

"[...] sic omnia membra emisere simul rutilum pro sanguine virus." (so, all his limbs at once emitter ruddy poison) and "omnia plenis membra fluunt venis totum est pro vulnere corpus." (All his limbs are awash with his copious veins; his entire body is one wound).

All the quoted descriptions seem to fit well with the typical fragility of the skin and tissues that is induced by Ebola Virus Disease12 (EVD) [12]. EVD is in fact able to trigger an easy and extensive spill of blood from any exposed to trauma body district. Blooding can also progress and become hemorrhagic, since EVD affects the coagulation, by inducing an increase in prothrombin and thromboplastin conversion times, as well as increasing the degradation of fibrin products.

"Sanguis erant lacrimae; quaecumque foramina novit umor, ab his largus manat cruor: ora redundant et patulae nares, sudor rubet;" (Gore flows abundantly from whatever opening moisture uses; his mouth and spreading nostrils run with it).

This list of symptoms appears to coincide in all respects with many specific of EVD: the bloody tears would be conjunctival hemorrhages; the blood out from each orifice and, in particular, the bleeding from the mouth and nose, are just epistaxis, hematuria, hematemesis and melena, all frequently found in subjects suffering from Ebola hemorrhagic fever [12].

The expression "totum est pro vulnere corpus" (his entire body is one wound) seems to resume and show the very essence of the Ebolavirus infection; it is able to inhibit the cell wall binding in almost any body tissue, pulling the cells apart and literally dissolving the tissue structure, thus causing a generalized bleeding.
Before discussing if a hemorrhagic fever outbreak could be an admittable explanation for the cases of death described by Lucan in book 9 of his epic, a phylogenetical review of Philoviridae.

The hypothesis is that the detailed description of the deaths of soldiers that Lucan makes in Book IX could be compatible with the appearance of an epidemic outbreak of a viral hemorrhagic fever. In the poem the alleged transmission of a lethal "virus" occurs through snake and other venomous pest bites. The Romans were obviously not aware of the existence of viruses as micro-organisms and the Latin term - precisely "virus" - has the meaning of "poison".

Assuming that the soldiers of the narrative had crossed the equator, which is possible and probable on the basis of the sources that have been examined and according to the geographical knowledge of the time, they may have followed the Nile for a long time, and then penetrated into tropical and equatorial areas. The hypothesis of such a path would not contrast with its duration - over a year - as it can be deduced from many historical sources $[13,14,15,16,17]$.

In this case the crossing of areas endemic for different Filoviridae, such as Marburg Marburgvirus, Sudan ebolavirus and Zaire ebolavirus, would have been inevitable.

Human hemorrhagic fevers can now also be caused by Lassa virus (family of Arenaviridae), but it is believed to exclude that this pathogen may have infected the troops of Cato Uticensis, for phylogenetic reasons. Lassa virus is indeed endemic from just over a thousand of years in the area of Nigeria, and a much more recent diffusion in the adjacent countries of West Africa. There is no specific evidence today about the existence of a pathogenic ancestor of this virus, at the time when occurred the events narrated by Lucan, but it seems at least likely to be able to exclude that it could be widespread in Central and Eastern Africa, along the course of the river Nile.

That said, the only lasting possibility is that a filovirus was to infect the soldiers.

From the epidemiological point of view the following risk factors support our hypothesis.

1. Food. The inevitable objective difficulties that the marching army had to deal with could justify the slaughter and consumption of bushmeat, including the local bats [18, 
19] that are widely regarded as the most probable reservoir for Filoviridae $[18,19,20,21,22,23,24,25]$. Feeding on bushmeat is the top-rated specific risk factor in EVD diffusion [26]. These viruses could also have been transmitted by non-human primates, as well as other mammals as pigs, rodents and cephalophes. Some arthropods are also suspected for transmission. Food transmission could therefore have been a risk factor [12].

2. Contact. Soldiers may have sheltered in caves or other areas frequented by bats, exposing themselves by contact and inhalation to infected dust and sprays, as well as contaminating their body, clothing and shoes with any organic material.

3. Funeral practices. Corpses - as any infected clothing - are all very important risk factors in the EVD diffusion to humans
$[27,28]$. The Romans were neither aware nor able to imagine or prevent in any way the risks deriving from this kind of exposure.

Assuming that many risk factors exhisted and exposure was possible, the question to aswear is whether, at the time when the facts (49-45 a.E.V.) happened and, therefore, from 2068 to 2064 years ago, any of the filoviruses known in the etiology of hemorrhagic fevers could have been circulating.

As demonstrated by S. A. Carroll and colleagues in 2013 [29]

(Figure 4), this family of viruses has been accompanying our species for over 10,000 years. However, this does not yet provide a definitive indication. Among them there are also some species totally harmless to humans, some pathogenic but not fatal and, lastly species able to cause extensive and fatal bleeding.

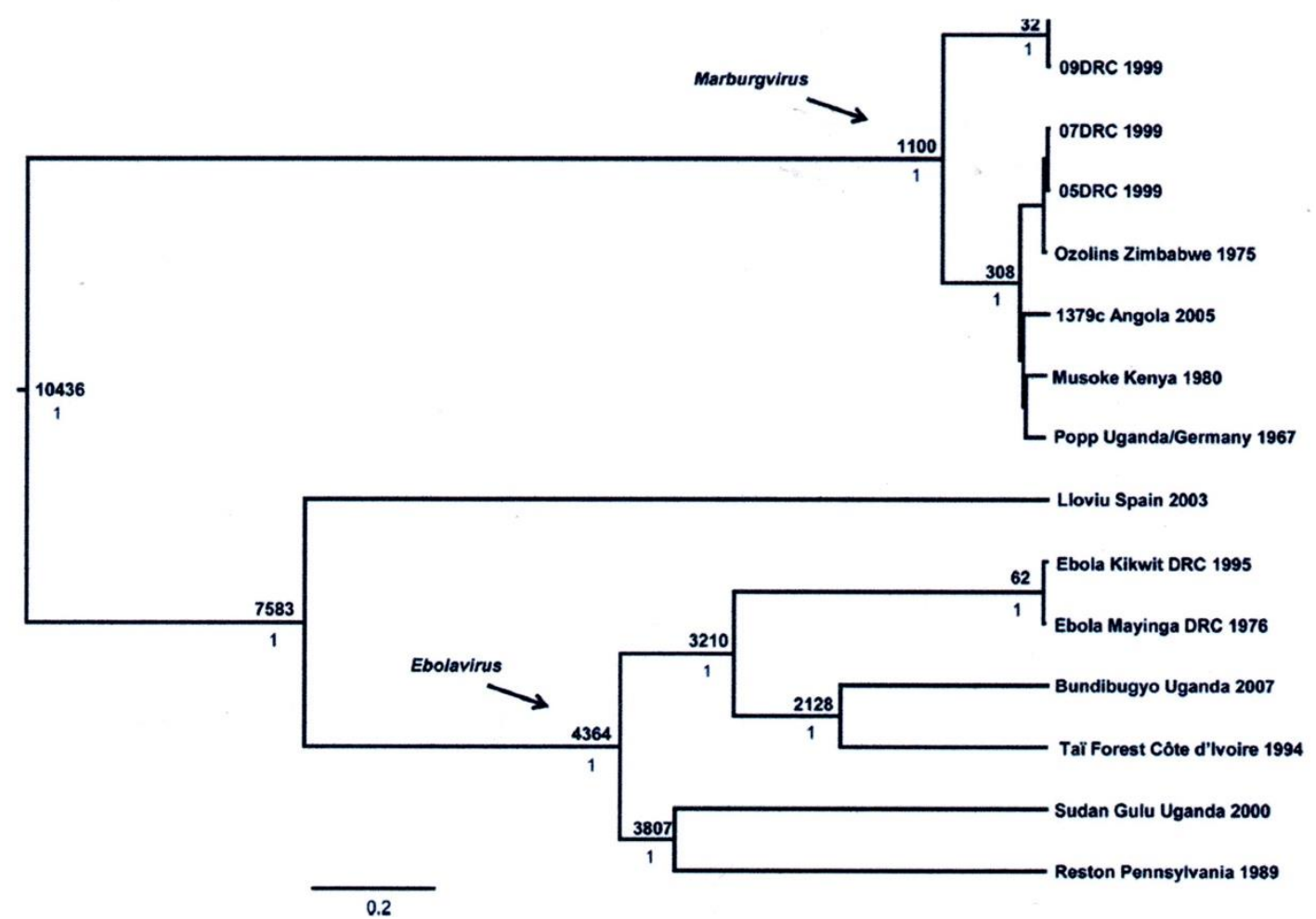

Fig. 4 - Phylogenetic tree of Filoviridae that demonstrates the appearance of the first ebolaviruses around 4.364 years ago [29].

In detail, the Filoviridae family, currently divided into three (or four) genera - i.e., Cuevavirus, Ebolavirus and Marburgvirus, plus the very recent introduction of Dianlovirus - contains the three already named Marburg marburgvirus species, Sudan ebolavirus and Zaire Ebola virus. These latter are also those whose distribution areas are the regions immediately above and below the equator, largely crossed by the river Nile.

The Marburg virus would have evolved only around 1100 years ago, so much time after the events described by Lucan. It is important to stress that the direct ancestor of the genus Marburgvirus was already present when the common ancestor of the two genera Ebolavirus and Cuevavirus 
appeared: about 10.436 years ago.

The pathogenicity of the Marburgvirus' ancestor is unknown, as that of any other species that evolved in the genus, and then became extinct, but what is currently observed is that the Marburgviruses, made up of the only Marburg species, cause high lethality hemorrhagic fevers.

Moreover, the Ebola virus disease, caused by Sudan and Zaire viruses - which respectively appeared evolutionarily about 3.800 years ago and about 3.200 years ago and both already present in the African regions where the events narrated by Lucan occurred - is a far more serious disease.

During the outbreak Zaire Ebola virus, occurred in West Africa in 2014-2016, after a rather nonspecific onset, with medium-high fever $\left(\mathrm{T} \geq 37.5^{\circ} \mathrm{C}\right)$ and symptoms similar to those of many diffused tropical infectious diseases - i.e. malaria, hepatitis and yellow fever - after 5-9 days, evidenced in about $18 \%$ of infected subjects, hemorrhagic manifestations similar to them described by Lucan: epistaxis, bleeding gums, hemoptysis, extended and frequent bruises, conjunctival bleeding, hematuria, bleeding evident from small bites and wounds.
The mortality rate of $18 \%$, which is not negligible, in previous outbreaks reached 30-36\% [30] and, in the 2018-19 epidemic in the DRC, exceeds $50 \%$. The fluctuations of pathogenicity and mortality can be explained by a slow ongoing adaptation of the RNA EV to humans [12]. Assuming about the pathogenicity of the virus in past time, it cannot be excluded that it may have been even greater than the current, especially in non-African and therefore never exposed populations [31] as the Romans.

The reason why Cato's troops should have gone so southward, up to cross the Equator, to circumvent the Syrtes region, is controversial.

A plausible hypothesis could be based on the Roman cartography $[32,33]$. The maps available during Lucan's age, in particular the "map of Pomponius Mela", 50 E.V. (figure 6), or the oldest "Eratosthenes map" (figure 5), showed a very short Africa [34]. In all these maps the continent extended much less along the meridians than it should have done, according to its real length. It spanned, from north to south, little more than the length of the Italian peninsula.

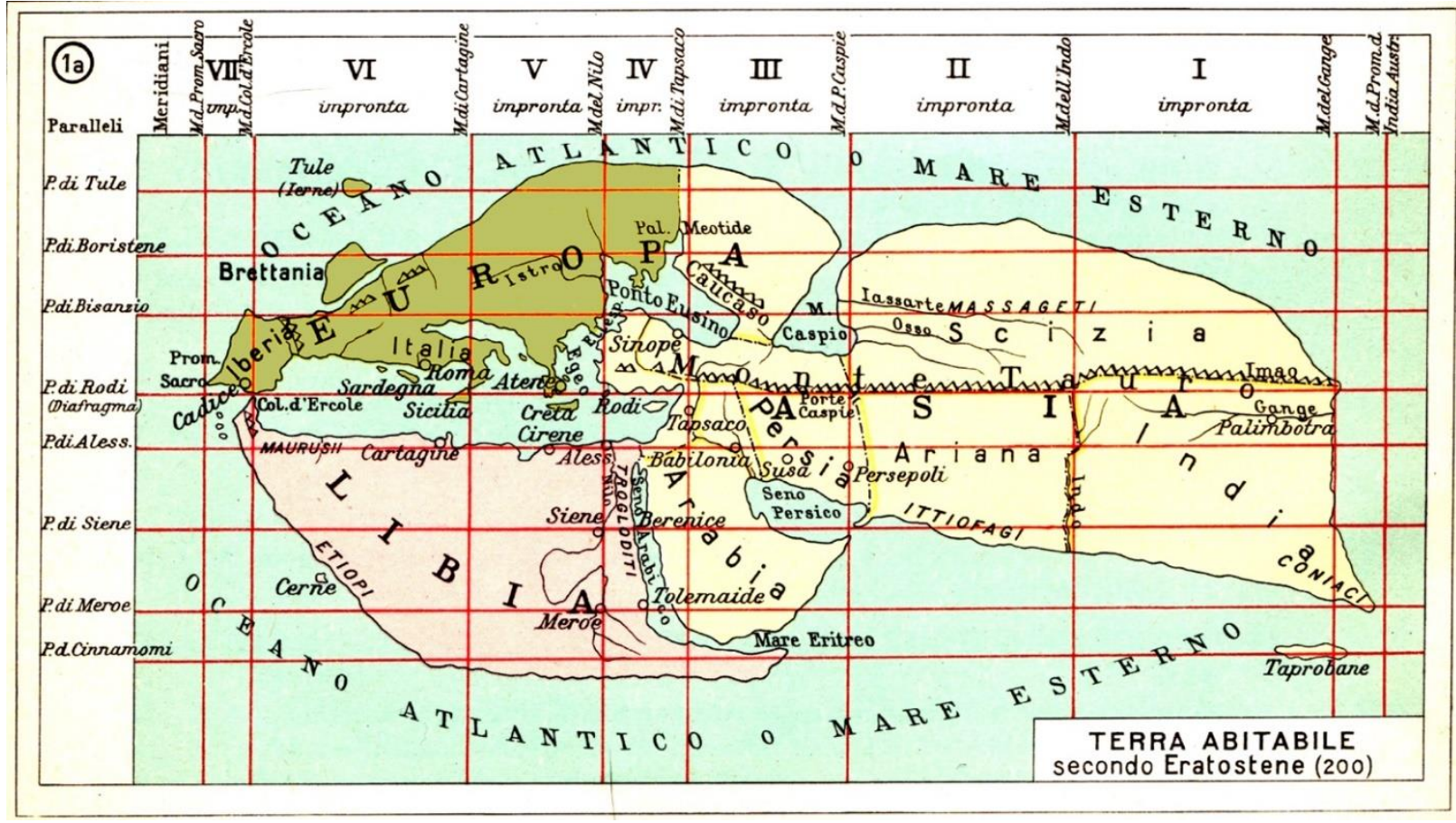

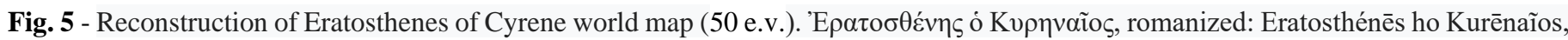
c. 276 a.E.V. - c. 195/194 a.E.V.) was a Greek polymath: a mathematician, geographer, poet, astronomer, and music theorist [32, 2]. Cartography by Prof. De Agostini, 1955, modif [36]. 




Fig. 6 - Reconstruction of Pomponius Mela's world map (50 E.V.) by Konrad Miller [35, 37]. It has been conjectured that Pomponius Mela may have been related in some way to Marcus Annaeus Mela, who was the son of Seneca the Elder and father of Lucan [38].

If, at the time of Lucan, the Equator had been located much northern than it actually is, a remarkable underestimation of the real penetration of roman troops in the African continent may have occurred. Then, from Cato's point of view, a trip starting from the North African coast and heading west, to avoid the Syrtes along a southward route, could have fairly gone south enough to cross the Equator.

\section{References}

1. Julius_CG._(2018)_Commentarii_de_Bello_Civili,_2.40. BUR_Classici_greci_e latini,_Milano,_Italia.

2. Strabo._(1942)_Geography_XVII._3.20_in:_The Geography of_Strabo,_with_an_English_translation_by_H_L_Jones, Based_partly_upon_the_unfinished_version_of_J_R Sitlington_Sterret._The_Loeb_Classical_Library,_London, New_York.
3. Annaeus. LM (2018) Bellum Civile_(B.C.), Liber_IX, 294-937._BUR_Classici_greci_e_latini,_Milano,_Italia.

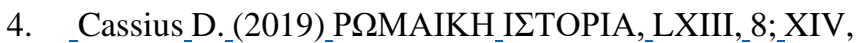
5._BUR_Classici_greci_e_latini,_Milano,_Italia.

5. Housman_AE._(1950)__Housman's__Astronomical Appendix_in_M._Annaei_Lucani_Belli_Civilis:_Libri Decem_-_Editorum_in_Usum_Editit._329-333.

6. _Curtius_L__Strabo's_Geography,_Book_II,_5._1-17.

7. Secundus_PG._(2011)_Naturalis_Hystoria_(N.H.),_V,81; XII,19._BUR_Classici_greci_e_latini,_Milano,_Italia.

8. Annaeus SL. (2014) De Terra Motu, Naturales Quaestiones (N.Q.), Liber IV, 2,6; Liber VI, 8,3-8,5. UTET, Roma, Italia.

9. Kirwan LP. (1954) Rome beyond the Southern Egyptian frontier. London. 
10. Vantini G, Nigrizia. 89 (2004).

11. Braund_SH._(2008)_Lucan,_Civil_War._Translated_with_an Introduction_and_Notes._OUP_e-book_ed.

12. Borgese_L,_Marangi_M,_Meledandri_M._(2017)_Ebola_e gli_altri_Filoviridae._Storia_Naturale,_Descrizione, Epidemiologia_e_Clinica._Alpes,_Roma,_Italia.

13. Wheeler_Sir_M._(1955)_Rome_beyond_the_Imperial frontiers,_Africa:_119-140,_Penguin_Books,_London.

14. Cary_M,_Warmington_EH._(1963)_The_Ancient_Explorers, Africa:_202-222,_Penguin_Books,_London.

15. Nicolet_C._L'inventaire_du_monde._(1988)_Géographie_et politique_aux_origines_de_l'Empire_romain,_Cap._I,_IV,_V, VIII._Hachette/Pluriel,_Paris,_France.

16. Asso_P._(2011)_Revising_nature_and_Roman_myth_in Brill's_companion_to_Lucan._Brill.

17. Buley_E,_Dinter_MT._(2013)_A_Companion_to_Neronian Age,_II,4,_III,13._Wiley_Blackwell.

18. Leroy_EM,_Kumulungui_B,_Pourrut_X,_Rouquet_P, Hassanin_A,_et_al._(2005)_Fruit_bats_as_reservoirs_of_Ebola virus._Nature._438:_575-576.

19. Leroy_EM,_Epelboin_A,_Mondonge_V,_Pourrut_X, Gonzalez_JP,_et_al._(2009)_Human_Ebola_outbreak resulting_from_direct_exposure_to_fruit_bats_in_Luebo, Democratic_Republic_of_Congo,_2007._Vector_Borne Zoonotic_Dis._9: 723-728.

20. Pourrut_X,_Delicat_A,_Rollin_PE,_Ksiazek_TG,_Gonzalez JP,_Leroy_EM._(2007)_Spatial_and_temporal_patterns_of Zaire_ebolavirus_antibody_prevalence_in_the_possible reservoir_bat_species._J_Infect_Dis;196_Suppl_2:_S176S183.

21. Pourrut_X,_Souris_M,_Towner_JS,_Rollin_PE,_Nichol_ST, Gonzales_JP,_et_al._(2009)_Large_serological_survey showing_cocirculation_of_Ebola_and_Marburg_viruses_in Gabonese_bat_populations,_and_a_high_seroprevalence_of both_viruses_in_Rousettus_aegyptiacus._BMC_Infect_Dis. 9: 159 .

22. Hayman_DT,_Emmerich_P,_Yu_M,_Wang_LF,_Suu-Ire_R, Fooks_AR,_et_al._(2010)_Long-term_survival_of_an_urban fruit_bat_seropositive_for_Ebola_and_Lagos_bat_viruses. PLoS_ONE._5:_e11978.
23. Laupland_KB,_Valiquette_L_._(2014)_Ebola_virus_disease. Can.____Infect._Dis._Med._Microbiol._25_(3):_128-129.

24. Monath_TP._(1999)_Ecology_of_Marburg_and_Ebola viruses:_speculations_and_directions_for_future research. Journal_Infect_Dis._179_Suppl_1:_S127-38.

25. Olival_KJ,_Islam_A,_Yu_M,_Anthony_SJ,_Epstein_JH,_Khan SA,_et_al._(2013)_Ebola_virus_antibodies_in_fruit_bats, Bangladesh._Emerg_Infect_Dis._19(2):_270-273.

26. Mann_E,_Streng_S,_Bergeron_J,_Kircher_A._(2015)_A Review_of the Role_of_Food_and the Food_System_in the Transmission_and_Spread_of_Ebolavirus._PLoS_Negl_Trop Dis._9(12):_e0004160.

27. International_Ebola_Response_Team,_Agua-Agum_J, Ariyarajah_A,_Aylward_B,_Bawo_L,_Bilivogui_P,_et_al. (2016)_Exposure_Patterns_Driving_Ebola_Transmission_in West_Africa:_A_Retrospective_Observational_Study. PLoS___Med.__13(11):___e1002170.___doi: 10.1371/journal.pmed.1002170.

28. Pandey_A,_Atkins_KE,_Medlock_J,_Wenzel_N,_Townsend JP,_Childs_JE,_et_al._(2014)_Strategies_for_containing Ebola_in_West_Africa._Science._346(6212):_991-995. doi:10.1126/science.1260612.

29. Carroll_SA,_Towner_JS,_Sealy_TK,_McMullan_LK, Khristova_ML,_et_al._(2013)_Molecular_evolution_of viruses_of_the_family_Filoviridae_based_on_97_wholegenome_sequences._J_Virol._87(5):_2608-16.

30. Beeching_NJ,_Fenech_M,_Houlihan_CF._(2014)_Ebola virus_disease._BMJ._349: g7348.

31. Gonzales_JP,_Josse_R,_Johnson_ED,_Merlin_M,_Georges AJ,_Abandja_J,_et_al._(1989)_Antibody_prevalence_against haemorrhagic fever_viruses_in_randomized_representative Central_Africans_populations._Res._Virol._140(4):_319331.

32. Roller_DW._(2010)_Eratosthenes'_Geography,_Princeton University_Press,_Princeton_and_Oxford.

33. Polo_Martin_B,_Olivos_H,_Alcompas_B._(2020)_La cartografia_romana,_in_La_cartografia_nell'antichità,_3235._Hachette,_Milano.

34. Dilke_OAW._(1985)_Greek_and_Roman_Maps,_caps._II and_IX,_app._IV,_app.VII;_HH_Scullard_-_Thames_and Hudson_LTD._London. 
35. Romer_Frank_E._(1998)_Pomponius_Mela's_Description_of the_World._Ann_Arbor:_University_of_Michigan_Press.

36. De Agostini G in Mori G. (1960)Atlante Storico Didattico - Evo Antico. Casa Editrice F. Le Monnier, Firenze.
37. Miller_K._(2008)_Mappae_mundi:_die_ältesten_Weltkarten, J._Roth,_1895,_Oxford_University,_Digitized_22_Dec.

38. Chisholm,_Hugh,_ed._(1911)_"Mela,_Pomponius". Encyclopædia__Britannica_(11th_ed.)._Cambridge University_Press. 